\title{
Water fluoridation in 40 Brazilian cities: 7 year
} analysis

\author{
Suzely Adas Saliba MOIMAZ1 ${ }^{1}$, Nemre Adas SALIBA ${ }^{1}$, Orlando SALIBA ${ }^{1}$, Doris Hissako SUMIDA ${ }^{2}$, Neila Paula de \\ SOUZA $^{3}$, Fernando Yamamoto CHIBA ${ }^{4}$, Cléa Adas Saliba GARBIN ${ }^{5}$
}

\begin{abstract}
1- DDS, MsC, PhD, Full Professor, Preventive and Social Dentistry Post-Graduation Program, Univ. Estadual Paulista - UNESP, Araçatuba, SP, Brazil. 2- DDS, MsC, PhD, Associate Professor, Preventive and Social Dentistry Post-Graduation Program, Univ. Estadual Paulista - UNESP, Araçatuba, SP, Brazil. 3- Master Degree candidate, Preventive and Social Dentistry Post-graduation Program, Univ. Estadual Paulista - UNESP, Araçatuba, SP, Brazil. 4- Doctor Degree candidate, Preventive and Social Dentistry Post-Graduation Program, Univ. Estadual Paulista - UNESP, Araçatuba, SP, Brazil. 5- DDS, MsC, PhD, Associate Professor and Coordinator of Preventive and Social Dentistry Post-Graduation Program, Univ. Estadual Paulista - UNESP, Araçatuba, SP, Brazil.
\end{abstract}

Corresponding address: Suzely Adas Saliba Moimaz - Faculdade de Odontologia de Araçatuba - UNESP - Programa de Pós-graduação em Odontologia Preventiva e Social - NEPESCO - Núcleo de Pesquisa em Saúde Coletiva - Departamento de Odontologia Infantil e Social - Rua José Bonifácio, 1193 - P.O. Box - 341 - 16015-050 - Araçatuba - SP - Brasil - Phone: ++55 01836363250 - e-mail: sasaliba@foa.unesp.br

Received: April 03, 2012 - Modification: October 05, 2012 - Accepted: November 30, 2012

\section{ABSTRACT}

$\mathrm{O}$ bjectives: Fluoride levels in the public water supplies of 40 Brazilian cities were analyzed and classified on the basis of risk/benefit balance. Material and Methods: Samples were collected monthly over a seven-year period from three sites for each water supply source. The samples were analyzed in duplicate in the laboratory of the Center for Research in Public Health - UNESP using an ion analyzer coupled to a fluoride-specific electrode. Results: A total of 19,533 samples were analyzed, of which 18,847 were artificially fluoridated and 686 were not artificially fluoridated. In samples from cities performing water fluoridation, $51.57 \%(n=9,720)$ had fluoride levels in the range of 0.55 to $0.84 \mathrm{mg}$ $\mathrm{F} / \mathrm{L} ; 30.53 \%(\mathrm{n}=5,754)$ were below $0.55 \mathrm{mg} \mathrm{F} / \mathrm{L}$ and $17.90 \%(n=3,373)$ were above 0.84 $\mathrm{mg} \mathrm{F} / \mathrm{L}$ (maximum concentration $=6.96 \mathrm{mg} \mathrm{F} / \mathrm{L}$ ). Most of the cities performing fluoridation that had a majority of samples with fluoride levels above the recommended parameter had deep wells and more than one source of water supply. There was some variability in the fluoride levels of samples from the same site and between collection sites in the same city. Conclusions: The majority of samples from cities performing fluoridation had fluoride levels within the range that provides the best combination of risks and benefits, minimizing the risk of dental fluorosis while preventing dental caries. The conduction of studies about water distribution systems is suggested in cities with high natural fluoride concentrations in order to optimize the use of natural fluoride for fluoridation costs and avoid the risk of dental fluorosis.

Key words: Fluorine. Fluoridation. Water supply. Oral health. Public health.

\section{INTRODUCTION}

Water is required to sustain life on the planet ${ }^{24}$, and access to clean water is one of the fundamental rights described in Article 3 of the Universal Declaration of Human Rights ${ }^{23}$. In Brazil, a portion of the population has been denied this right, since $17 \%$ of Brazilian cities do not have municipal water systems ${ }^{11}$.

An inverse relationship between the fluoride levels in drinking water and the incidence of dental caries was first observed in the United States at the beginning of the last century ${ }^{14}$. This observation, in association with later studies, resulted in the addition of fluoride to public water supplies to prevent dental caries, a strategy that is now recommended for all citizens ${ }^{22}$.

The first implementation of a water fluoridation system occurred in Grand Rapids, Michigan, USA, in 1942. Widespread adoption of fluoridation potentially reduces the incidence of caries by $50 \%$, and for this reason fluoridation has been used in several countries ${ }^{17}$.

In 1953, Baixo Gandu City in the state of Espírito 
Santo became the first Brazilian city to employ water supply fluoridation ${ }^{19}$. Some years later, Federal Law number 6050 (May $24^{\text {th }}, 1974$ ) required the addition of fluoride to public water supplies in cities with water treatment systems ${ }^{1}$. This measure is considered one of the 10 most important public health advances in the $20^{\text {th }}$ century ${ }^{5}$ because it established a comprehensive, economical, and effective means of continuously providing a health benefit to a large population at minimal risk.

Periodic analyses of fluoride levels in water supplies originated with the goal of providing uniform fluoride levels independent of natural concentrations or water supply companies. The external control consists in the principle that if any service offers risk or represents a protection factor for public health, the control regarding producer, production process, distribution and consumption,

Table 1- Distribution of samples from public water supplies from 40 Brazilian cities, according to fluoride concentration (mgF/L), from November 2004 to October 2011

\begin{tabular}{|c|c|c|c|c|c|c|c|c|c|c|c|c|c|c|}
\hline \multirow{3}{*}{$\begin{array}{c}\text { City } \\
\text { Artificial Fluoride }\end{array}$} & \multicolumn{14}{|c|}{ Classification of fluoride levels } \\
\hline & \multicolumn{2}{|c|}{$0.00-0.44$} & \multicolumn{2}{|c|}{$0.45-0.54$} & \multicolumn{2}{|c|}{$0.55-0.84$} & \multicolumn{2}{|c|}{$0.85-1.14$} & \multicolumn{2}{|c|}{$1.15-1.44$} & \multicolumn{2}{|c|}{$\geq 1.45$} & \multicolumn{2}{|c|}{ Total } \\
\hline & $\mathbf{n}$ & $\%$ & $\mathbf{n}$ & $\%$ & n & $\%$ & $\mathbf{n}$ & $\%$ & $\mathbf{n}$ & $\%$ & $\mathbf{n}$ & $\%$ & $\mathbf{n}$ & $\%$ \\
\hline Alto Alegre & 9 & 3.6 & 17 & 6.8 & 221 & 88.8 & 2 & 0.8 & 0 & 0 & 0 & 0 & 249 & 100 \\
\hline Araçatuba & 29 & 4.2 & 91 & 13 & 455 & 65.2 & 119 & 17 & 0 & 0 & 4 & 0.6 & 698 & 100 \\
\hline Auriflama & 16 & 6.6 & 6 & 2.5 & 219 & 90.9 & 0 & 0 & 0 & 0 & 0 & 0 & 241 & 100 \\
\hline Avanhandava & 21 & 14.9 & 11 & 7.8 & 94 & 66.7 & 12 & 8.5 & 0 & 0 & 3 & 2.1 & 141 & 100 \\
\hline Barbosa & 24 & 3.7 & 35 & 5.4 & 493 & 76.4 & 77 & 11.9 & 6 & 0.9 & 10 & 1.6 & 645 & 100 \\
\hline Bento de Abreu & 13 & 5.2 & 44 & 17.7 & 176 & 70.7 & 15 & 6 & 1 & 0.4 & 0 & 0 & 249 & 100 \\
\hline Bilac & 40 & 29.6 & 9 & 6.7 & 47 & 34.8 & 28 & 20.7 & 6 & 4.4 & 5 & 3.7 & 135 & 100 \\
\hline Birigui & 254 & 11.7 & 82 & 3.8 & 832 & 38.4 & 866 & 40 & 108 & 5 & 25 & 1.2 & 2,167 & 100 \\
\hline Braúna & 255 & 36.6 & 51 & 7.3 & 262 & 37.6 & 109 & 15.6 & 12 & 1.7 & 8 & 1.1 & 697 & 100 \\
\hline Brejo Alegre & 6 & 2.6 & 27 & 11.7 & 185 & 80.1 & 10 & 4.3 & 0 & 0 & 3 & 1.3 & 231 & 100 \\
\hline Buritama & 576 & 39.3 & 113 & 7.7 & 623 & 42.5 & 122 & 8.3 & 26 & 1.8 & 6 & 0.4 & 1,466 & 100 \\
\hline Castilho & 140 & 11.8 & 167 & 14.1 & 663 & 55.9 & 159 & 13.4 & 24 & 2 & 33 & 2.8 & 1,186 & 100 \\
\hline Clementina & 651 & 50.6 & 53 & 4.1 & 406 & 31.5 & 117 & 9.1 & 21 & 1.6 & 39 & 3 & 1,287 & 100 \\
\hline Coroados & 0 & 0 & 9 & 3.6 & 233 & 93.6 & 7 & 2.8 & 0 & 0 & 0 & 0 & 249 & 100 \\
\hline Gabriel Monteiro & 12 & 4.8 & 7 & 2.8 & 215 & 86.3 & 14 & 5.6 & 1 & 0.4 & 0 & 0 & 249 & 100 \\
\hline Glicério & 381 & 54 & 31 & 4.4 & 250 & 35.5 & 29 & 4.1 & 13 & 1.8 & 1 & 0.1 & 705 & 100 \\
\hline Guaraçaí & 295 & 33.9 & 67 & 7.7 & 339 & 38.9 & 140 & 16.1 & 14 & 1.6 & 16 & 1.8 & 871 & 100 \\
\hline Guararapes & 8 & 3.3 & 15 & 6.1 & 192 & 78 & 31 & 12.6 & 0 & 0 & 0 & 0 & 246 & 100 \\
\hline Guzolândia & 6 & 2.4 & 10 & 4 & 224 & 90 & 9 & 3.6 & 0 & 0 & 0 & 0 & 249 & 100 \\
\hline Ilha Solteira & 13 & 5.3 & 14 & 5.8 & 213 & 87.7 & 0 & 0 & 0 & 0 & 3 & 1.2 & 243 & 100 \\
\hline Itapura & 348 & 50.4 & 69 & 10 & 161 & 23.3 & 82 & 11.9 & 20 & 2.9 & 11 & 1.6 & 691 & 100 \\
\hline Lavínia & 276 & 30.9 & 120 & 13.5 & 299 & 33.5 & 147 & 16.5 & 41 & 4.6 & 9 & 1 & 892 & 100 \\
\hline Lourdes & 3 & 1.2 & 30 & 12 & 213 & 84.9 & 5 & 2 & 0 & 0 & 0 & 0 & 251 & 100 \\
\hline Mirandópolis & 74 & 16 & 83 & 18 & 218 & 47.2 & 63 & 13.6 & 17 & 3.7 & 7 & 1.5 & 462 & 100 \\
\hline Muruntinga do Sul & 164 & 67.5 & 34 & 14 & 39 & 16 & 6 & 2.5 & 0 & 0 & 0 & 0 & 243 & 100 \\
\hline Nova Castilho & 31 & 14 & 42 & 19 & 74 & 33.5 & 44 & 19.9 & 13 & 5.9 & 17 & 7.7 & 221 & 100 \\
\hline Nova Independência & 126 & 28 & 38 & 8.4 & 219 & 48.7 & 48 & 10.7 & 13 & 2.9 & 6 & 1.3 & 450 & 100 \\
\hline Nova Luzitânia & 2 & 2.4 & 31 & 37.8 & 49 & 59.8 & 0 & 0 & 0 & 0 & 0 & 0 & 82 & 100 \\
\hline Penápolis & 1 & 0.4 & 19 & 7.9 & 203 & 84.6 & 17 & 7.1 & 0 & 0 & 0 & 0 & 240 & 100 \\
\hline Piacatú & 8 & 3.2 & 14 & 5.6 & 214 & 84.9 & 13 & 5.2 & 0 & 0 & 3 & 1.2 & 252 & 100 \\
\hline Rubiácea & 20 & 4.3 & 58 & 12.5 & 354 & 76.3 & 27 & 5.8 & 2 & 0.4 & 3 & 0.6 & 464 & 100 \\
\hline Santópolis do Aguapeí & 4 & 1.8 & 2 & 0.9 & 219 & 96.1 & 3 & 1.3 & 0 & 0 & 0 & 0 & 228 & 100 \\
\hline Santo Antônio do Aracanguá & 171 & 37.5 & 55 & 12.1 & 169 & 37.1 & 50 & 11 & 6 & 1.3 & 5 & 1.1 & 456 & 100 \\
\hline Sud Mennucci & 2 & 0.8 & 51 & 20.5 & 196 & 78.7 & 0 & 0 & 0 & 0 & 0 & 0 & 249 & 100 \\
\hline Suzanápolis & 162 & 29 & 37 & 6.6 & 149 & 26.7 & 109 & 19.5 & 59 & 10.6 & 43 & 7.7 & 559 & 100 \\
\hline Turiúba & 6 & 2.5 & 17 & 7.1 & 211 & 87.9 & 6 & 2.5 & 0 & 0 & 0 & 0 & 240 & 100 \\
\hline Valparaíso & 34 & 5.1 & 14 & 2.1 & 391 & 59 & 220 & 33.2 & 4 & 0.6 & 0 & 0 & 663 & 100 \\
\hline Subtotal & 4,181 & 22.2 & 1,573 & 8.3 & 9,720 & 51.6 & 2,706 & 14.4 & 407 & 2.2 & 260 & 1.4 & 18,847 & 100 \\
\hline \multicolumn{15}{|l|}{ Natural Fluoride } \\
\hline Andradina & 114 & 50.7 & 7 & 3.1 & 38 & 16.9 & 38 & 16.9 & 18 & 8 & 10 & 4.4 & 225 & 100 \\
\hline Luiziânia & 4 & 1.8 & 6 & 2.6 & 216 & 95.2 & 0 & 0 & 1 & 0.4 & 0 & 0 & 227 & 100 \\
\hline Pereira Barreto & 0 & 0 & 0 & 0 & 58 & 24.8 & 175 & 74.8 & 1 & 0.4 & 0 & 0 & 234 & 100 \\
\hline Subtotal & 118 & 17.2 & 13 & 1.9 & 312 & 45.5 & 213 & 31 & 20 & 2.9 & 10 & 1.5 & 686 & 100 \\
\hline Total & 4,299 & 22 & 1,586 & 8.1 & 10,032 & 51.4 & 2,919 & 14.9 & 427 & 2.2 & 270 & 1.4 & 19,533 & 100 \\
\hline
\end{tabular}


should be controlled by State Institutions. It has evolved into a way of improving the quality and consistency of fluoridation, and has been instituted in many different regions of Brazil12,16,18.

The existence of mechanisms that enable the control of naturally-occurring and supplemental fluoride levels in water maximizes the benefits of preventing dental caries while minimizing the risk of dental fluorosis ${ }^{6,8,13}$.
Previous studies ${ }^{20,21}$ have measured the fluoride levels in public water supplies and classified samples into "appropriate" and "inappropriate" categories. However, this dichotomous classification limits the interpretation of the water analysis results.

We classified fluoride levels in samples from public water supplies in 40 cities, according to the recently proposed risk/benefit criteria ${ }^{6}$, and investigated the consistency of fluoride

Table 2- Number of collection sites, utilization of natural or artificially added fluoride in the public water supply, and the type of water supply source for the 40 Brazilian cities in this study from November 2004 to October 2011

\begin{tabular}{|c|c|c|c|c|c|c|}
\hline \multirow[t]{2}{*}{ Cities } & \multirow{2}{*}{$\begin{array}{l}\text { Collection } \\
\text { sites }\end{array}$} & \multicolumn{2}{|c|}{ Fluoride } & \multicolumn{3}{|c|}{ Water sources } \\
\hline & & Artificial & Natural & Shallow well & Deep well & $\begin{array}{c}\text { River, stream } \\
\text { or dam }\end{array}$ \\
\hline Alto Alegre & 3 & $x$ & & & $\mathrm{X}$ & \\
\hline Andradina & 3 & & $x$ & & $x$ & \\
\hline Araçatuba & 9 & $\mathrm{X}$ & & $\mathrm{X}$ & & $x$ \\
\hline Auriflama & 3 & $x$ & & $x$ & & $x$ \\
\hline Avanhandava & 3 & $x$ & & & & $x$ \\
\hline Barbosa & 9 & $x$ & & $\mathrm{X}$ & & \\
\hline Bento de Abreu & 3 & $x$ & & $x$ & & \\
\hline Bilac & 12 & $\mathrm{X}$ & & $X$ & & \\
\hline Birigui & 42 & $x$ & & $\mathrm{X}$ & $x$ & \\
\hline Braúna & 9 & $\mathrm{X}$ & & $X$ & & \\
\hline Brejo Alegre & 3 & $x$ & & $\mathrm{X}$ & & \\
\hline Buritama & 24 & $\mathrm{X}$ & & $X$ & & \\
\hline Castilho & 15 & $x$ & & $x$ & & \\
\hline Clementina & 18 & $x$ & & $X$ & & \\
\hline Coroados & 3 & $x$ & & $x$ & & \\
\hline Gabriel Monteiro & 3 & $x$ & & & & $x$ \\
\hline Glicério & 9 & $\mathrm{X}$ & & $x$ & & \\
\hline Guaraçai & 12 & $x$ & & $X$ & & \\
\hline Guararapes & 3 & $x$ & & & $x$ & $x$ \\
\hline Guzolândia & 3 & $\mathrm{X}$ & & $x$ & & \\
\hline Ilha Solteira & 3 & $x$ & & $x$ & & \\
\hline Itapura & 12 & $\mathrm{X}$ & & $x$ & & \\
\hline Lavínia & 12 & $\mathrm{X}$ & & $\mathrm{X}$ & & \\
\hline Lourdes & 3 & $\mathrm{X}$ & & & $x$ & \\
\hline Luiziânia & 3 & & $x$ & $x$ & & \\
\hline Mirandópolis & 6 & $x$ & & $\mathrm{X}$ & & $\mathrm{X}$ \\
\hline Murutinga do Sul & 3 & $x$ & & & $x$ & \\
\hline Nova Castilho & 3 & $\mathrm{X}$ & & & $\mathrm{X}$ & \\
\hline Nova Independ & 6 & $x$ & & $x$ & & \\
\hline Nova Luzitânia & 3 & $\mathrm{X}$ & & $x$ & & \\
\hline Penápolis & 3 & $\mathrm{X}$ & & & & $\mathrm{X}$ \\
\hline Pereira Barreto & 3 & & $x$ & & $\mathrm{X}$ & \\
\hline Piacatu & 3 & $x$ & & & $x$ & $\mathrm{X}$ \\
\hline Rubiácea & 6 & $\mathrm{X}$ & & & $\mathrm{X}$ & \\
\hline Santo Antônio do Aracanguá & 6 & $x$ & & $x$ & & \\
\hline Santópolis do Aguapeí & 3 & $\mathrm{X}$ & & $\mathrm{X}$ & & $\mathrm{X}$ \\
\hline Sud Mennucci & 3 & $x$ & & $x$ & & \\
\hline Suzanápolis & 9 & $x$ & & $x$ & & \\
\hline Turiúba & 3 & $x$ & & & & \\
\hline Valparaíso & 9 & $x$ & & $x$ & & \\
\hline
\end{tabular}


Table 3- Classification of fluoride levels in water for locations where the mean of maximum annual temperatures are between $26.3^{\circ} \mathrm{C}$ and $32.5^{\circ} \mathrm{C}$

\begin{tabular}{ccc}
\hline $\begin{array}{c}\text { Fluoride level } \\
\text { (mgF/L) }\end{array}$ & Benefit & Risk \\
\hline 0.00 to 0.44 & insignificant & insignificant \\
0.45 to 0.54 & minimum & low \\
0.55 to 0.84 & maximum & low \\
0.85 to 1.14 & maximum & moderate \\
1.15 to 1.44 & questionable & high \\
1.45 or more & harm & very high \\
\hline
\end{tabular}

concentrations in the samples over a 7-year period.

\section{MATERIAL AND METHODS}

\section{Type and period of study}

A longitudinal study was conducted using sampling sites in 40 cities located in São Paulo State, Brazil. To conduct the study, formal and personal contacts were made with the secretaries of health, oral health coordinators and those responsible for the public water supply of each municipality. The trial included all cities $(n=40)$ belonging to the Regional Health Department II (RHDII). Samples were collected monthly from

Table 4- Annual mean of fluoride levels (mg F/L), standard deviation (SD), observed in analyzed water samples, according to the cities in this study, from November 2004 to October 2011 (ND= not determined)

\begin{tabular}{|c|c|c|c|c|c|c|c|c|c|c|c|c|c|c|c|c|}
\hline \multirow[t]{2}{*}{ City } & \multicolumn{2}{|c|}{2004} & \multicolumn{2}{|c|}{2005} & \multicolumn{2}{|c|}{2006} & \multicolumn{2}{|c|}{2007} & \multicolumn{2}{|c|}{2008} & \multicolumn{2}{|c|}{2009} & \multicolumn{2}{|c|}{2010} & \multicolumn{2}{|c|}{2011} \\
\hline & Mean & SD & Mean & SD & Mean & SD & Mean & SD & Mean & SD & Mean & SD & Mean & SD & Mean & SD \\
\hline Araçatuba & 0.64 & 0.12 & $\overline{0.53}$ & 0.14 & 0.66 & 0.1 & 0.79 & 0.1 & 0.76 & 0.13 & 0.81 & 0.38 & 0.73 & 0.14 & 0.82 & 0.08 \\
\hline Auriflama & 61 & 0.13 & 0.42 & 0.32 & 0.58 & 0.14 & 0.7 & 0.03 & 0.65 & 0.05 & 0.67 & 0.03 & 0.67 & .02 & .68 & 0.02 \\
\hline Barbosa & 39 & 0.2 & 0.6 & 0.3 & 0.75 & .24 & 0.78 & 0.3 & 0.75 & 0.17 & 0.85 & 0.14 & .71 & .17 & 0.6 & 0.11 \\
\hline Bento de Abreu & 53 & 0.17 & 0.6 & 1 & 0.65 & .13 & 0.66 & 0.18 & 0.57 & 0.08 & .58 & 0.12 & .72 & .13 & 0.77 & 0.09 \\
\hline Bilac & 0.12 & 0.07 & 0.66 & 0.47 & 0.76 & 0.43 & ND & & ND & & ND & & ND & & ND & \\
\hline Braúna & 0.06 & 0.01 & 0.05 & 0.02 & 0.07 & 0.02 & 0.57 & 0.26 & 0.69 & 0.2 & 0.74 & 0.26 & 0.71 & 0.36 & 0.83 & 0.19 \\
\hline Buritama & 0.1 & 0.01 & 0.08 & 0.04 & 0.54 & 0.36 & 0.5 & 0.44 & 0.33 & 0.29 & 0.53 & 0.32 & 0.58 & 26 & 0.63 & 0.3 \\
\hline Gabriel Monte & 0.76 & 0.02 & .67 & 0.08 & 0.69 & 0.06 & 0.71 & 0.05 & 0.72 & 0.09 & 0.71 & 0.06 & .66 & 0.24 & 0.67 & 0.18 \\
\hline Glicério & 0.41 & 0.12 & 0.33 & 0.18 & 0.42 & 0.19 & 0.39 & 0.19 & 0.4 & 0.19 & 0.43 & 0.25 & .69 & 0.17 & 0.76 & 0.37 \\
\hline Lourdes & 0.54 & 0.05 & 0.56 & 0.08 & 0.65 & 0.08 & 0.67 & 0.05 & 0.66 & 0.06 & 0.71 & 0.07 & 0.62 & 0.07 & 0.62 & 0.11 \\
\hline Luiziânia & 55 & 0.12 & 0.63 & 0.15 & 0.59 & 0.13 & 0.66 & 0.02 & 0.66 & 0.03 & 0.66 & 0.02 & 0.66 & 0.02 & 0.7 & 0.03 \\
\hline Muruntinga do Sul & 0.62 & 0.18 & 0.37 & 0.12 & 0.49 & 0.19 & 0.49 & 0.2 & 0.33 & 0.11 & 0.38 & 0.19 & 0.32 & 0.21 & 0.23 & 0.08 \\
\hline Pereira & 88 & & 0.79 & 0.07 & 0.88 & 0.05 & 0.91 & 0.07 & 0.9 & 0.04 & 0.88 & .04 & .88 & .02 & 0.86 & 0.06 \\
\hline Rubiácea & 78 & 0.05 & 0.64 & 0.21 & 0.7 & 0.14 & 0.63 & & 0.6 & 0.1 & 0.58 & 0.12 & .74 & 0.21 & 0.73 & 0.12 \\
\hline $\begin{array}{c}\text { Santópolis do } \\
\text { Aguapeí }\end{array}$ & 0.69 & 0.02 & 0.66 & 0.13 & 0.69 & 0.08 & 0.68 & 0.06 & 0.67 & 0.07 & 0.7 & 0.05 & 0.66 & 0.05 & 0.68 & 0.13 \\
\hline Suzan & 05 & 0.02 & 0 & 0.13 & 0.61 & & 0.82 & 0 & 0.81 & 0 & 2. & 6 & 93 & 3 & 0.59 & 0.24 \\
\hline Turi & 64 & 0 & 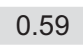 & 0. & 0.58 & 5 & 0.66 & 0 & 0.64 & & 0.65 & & 68 & 7 & & 0.17 \\
\hline Alto Alegre & .54 & 0.14 & 0.67 & 0.08 & 0.66 & 0.06 & 0.61 & 0.07 & 0.64 & 0.06 & 0.66 & 07 & .6 & 0 & 0.63 & 0.09 \\
\hline Andra & 74 & 0.16 & .77 & 0.22 & 0.65 & 0.47 & 0.59 & 0.41 & 0.55 & 0.38 & 0.51 & 0.36 & 0.63 & 0.49 & 0.75 & 0.4 \\
\hline Avanha & 0.89 & 0.17 & 0.66 & 0.22 & 0.48 & 0.01 & 5.66 & 3.24 & 0.76 & 0.09 & 0.65 & & 0.49 & & 0.64 & 0.22 \\
\hline Birigui & 21 & & 0.62 & 0.29 & 0.69 & 0.31 & 0.64 & 0 & 0.76 & 0. & 0.81 & 8 & 83 & 8 & 9 & 0.37 \\
\hline Brejo & 54 & 6 & 59 & 0.09 & 0.65 & 0.14 & 0.71 & 0.05 & 0.69 & 0. & 0.73 & 3 & 0.63 & .05 & 0.79 & 0.04 \\
\hline Cast & 0.47 & 0.17 & 0.62 & 0.2 & 0.73 & 0.28 & 0.7 & 0. & 0.78 & 0.17 & 0.74 & 0.25 & 0.64 & 0.2 & 0.72 & 0.53 \\
\hline Clementina & & 0.02 & 0.07 & 0.03 & 1 & 0.11 & 0.58 & 1. & 0.53 & 0.58 & 0.41 & 0.67 & 0.94 & 3.25 & 0.74 & 0.16 \\
\hline Corc & 0 & & 0 & 0.0 & & & 0.67 & 0. & 0.73 & 0. & 0.63 & & 59 & 4 & 0.64 & 0.06 \\
\hline Guar & 0 & & & & & & & & 0.49 & & & & 78 & & 0.85 & 0.17 \\
\hline Guararapes & 0.6 & 0 & 61 & 0.06 & 0.65 & 0 & 0.72 & 0. & 0.79 & 0. & 0.73 & 0.17 & 0.68 & 0.09 & 0.73 & 0.11 \\
\hline Guzo & 0.71 & 0.01 & 0.66 & 0.06 & 0.75 & 0.07 & 0.73 & 0.08 & 0.63 & 0.14 & 0.66 & 0.07 & 0.62 & 0.09 & 0.75 & 0.08 \\
\hline Ilha Solteira & 63 & 0.08 & 0.66 & 0.07 & 0.61 & 0.18 & 1.1 & 1.72 & 0.55 & 0.18 & 0.63 & 0.07 & 0.59 & 0.13 & 0.66 & 0.04 \\
\hline Itapura & 0 & 0.0 & 0.3 & 0.2 & 0.1 & & 0. & & 0.45 & & 0 & & 0.62 & 0.46 & 0.58 & 0.37 \\
\hline Lavínia & & & & & & & 0.67 & & & & & & & & 0.64 & 0.34 \\
\hline Mirandópolis & .48 & 0.12 & 0.69 & 0.17 & 0.73 & 0.26 & 0.7 & 0.31 & 0.79 & 0.45 & 0.62 & 0.23 & 0.57 & 0.15 & 0.49 & 0.22 \\
\hline Nova Castilho & 53 & 0.1 & 0.52 & 0.09 & 0.78 & 0.32 & 0.63 & 0.54 & 0.75 & 0.5 & 0.94 & 0.36 & 0.83 & 0.28 & 0.87 & 0.48 \\
\hline $\begin{array}{c}\text { Nova } \\
\text { Independência }\end{array}$ & 0.71 & 0.1 & 0.69 & 0.41 & 0.58 & 0.44 & 0.34 & 0.21 & 0.59 & 0.17 & 0.76 & 0.1 & 0.67 & 0.24 & 0.69 & 0.18 \\
\hline Nova Luzitânia & & & & & & & & 0.13 & 0. & 0. & 0. & & ID & & 0.67 & 0.08 \\
\hline Penápolis & 0.8 & & 0.6 & 0.0 & 0.7 & & 0.76 & & 0.64 & 0.0 & 0.61 & 0.06 & 0.6 & 0.07 & 0.62 & 0.07 \\
\hline Piacatú & & 0.06 & 0.61 & 0.1 & 0.67 & 0.09 & 0.8 & 0.45 & 0.64 & 0.1 & 0.75 & 0.07 & 0.74 & 0.05 & 0.72 & 0.17 \\
\hline $\begin{array}{l}\text { Sant. Ant. do } \\
\text { Aracanguá }\end{array}$ & 0.07 & 0.01 & 0.4 & 0.36 & 0.72 & 0.15 & 0.51 & 0.24 & 0.52 & 0.18 & 0.37 & 0.29 & 0.79 & 0.38 & 0.65 & 0.14 \\
\hline Sud Mennucci & 0.51 & 0.06 & 0.51 & 0.07 & 0.63 & & 0.57 & 0.06 & 0.57 & 0.04 & 0.63 & 0.05 & 0.58 & 0.03 & 0.67 & 0.08 \\
\hline Valparaíso & 0.8 & 0.08 & 0.72 & 0.2 & 0.79 & 0.25 & 0.79 & 0.21 & 0.73 & 0.13 & 0.73 & 0.13 & 0.8 & 0.13 & 0.81 & 0.06 \\
\hline
\end{tabular}


public water distribution systems from November 2004 to October 2011, yielding 84 months of analysis.

\section{Identification of collection sites}

Sample collection sites were selected according to the number of water sources or treatment plants in each city. Each source was assigned three collection sites ${ }^{21}$. Maps of the distribution system were obtained from the water treatment authority and used to randomize the collection sites, including all sources of treated water.

\section{Collection of water samples}

Polyethylene bottles $(50 \mathrm{~mL})$ were rinsed with deionized water and identified with the city name, collection site, and date. At the collection site, the bottles were rinsed three times with the water comprised of the sample. Samples were collected on the same day during the first week of each month and analyzed in the laboratory of NEPESCO (Center for Research in Public Health) at the Universidade Estadual Paulista - UNESP.

\section{Analysis of fluoride levels}

The fluoride content of the samples was determined potentiometrically using an ion analyzer (Orion EA940) equipped with a fluoride ion-specific electrode (Orion 9609BN). A calibration curve was constructed over the expected concentration range of the samples using standards containing 0.1 , $0.2,0.4,0.8$, and $1.6 \mathrm{mg} \mathrm{F} / \mathrm{L}$ and prepared using $\mathrm{NaF}$. The standards were prepared in triplicate to minimize the effect of measurement errors. To avoid interference from other ions, an equal volume $(1 \mathrm{~mL})$ of TISAB II ${ }^{\circledR}$ solution was added to each sample (Orion, USA). Duplicate measurements of each sample were recorded using the Excel software (Microsoft Office 2010), and values of $\mathrm{mV}$ were converted to $\mathrm{mg} F / L$ using a standard curve [correlation coefficient ( $r$ ) 0.999]. When the difference between the duplicate readings was larger than $1 \mathrm{mV}$, a third reading was obtained for confirmation of the data.

\section{Sample classification}

Considering that the average maximum annual temperatures in the cities participating in this study were between $26.3^{\circ} \mathrm{C}$ and $32.5^{\circ} \mathrm{C}$, the fluoride level offering the best risk-benefit combination was 0.55 $0.84 \mathrm{mg} \mathrm{F} / \mathrm{L}$ (Table 1$)^{6}$.

\section{Statistical analysis}

Descriptive analyses were based on absolute and relative frequencies.

\section{RESULTS}

Fluoride was not added to public water supplies in $7.5 \%(n=3)$ of the cities, and in other cities, ion aggregation occurred in at least one water source (Table 2).

A variety of water sources are used in the composition of the water supply system of the cities, among which can be observed $67.5 \%(n=27)$ from shallow wells, $25 \%(n=10)$ from deep wells, and $22.5 \%(n=9)$ from rivers, streams, or dams. Some cities had more than one source of water supply (Table 2). Between November 2004 and October $2011,19,533$ samples of water were analyzed in duplicate from 291 collection sites in 40 cities, totaling 39,066 analyses (Table 3). In some months, the collect of samples was not performed due to difficulties in accessing the location.

In $62 \%(n=24)$ of the cities, most of the samples were classified into the category that offer the best combination of risk-benefit ( 0.55 to $0.84 \mathrm{mg} \mathrm{F} / \mathrm{L}$ ). It was observed that $51.57 \%$ of the samples from cities with fluoridated water and $45.48 \%$ of the samples from cities with non-fluoridated water were included in this category.

Fluoride levels below $0.55 \mathrm{mg} \mathrm{F} / \mathrm{L}$ were found in $30.13 \%$ of the water samples. Of this total, $30.53 \%$ were in cities providing fluoridated water. Among the non-fluoridated water samples, $35.42 \%$ had fluoride levels above $0.84 \mathrm{mg} \mathrm{F} / \mathrm{L}$.

Table 4 shows the variation of fluoride average concentrations $(\mathrm{mgF} / \mathrm{L})$ of the water samples, and the standard variation, according to the cities, during 7 years of analysis.

\section{DISCUSSION}

Discussions of optimal fluoride levels in public water supplies are ongoing among researchers worldwide. The United States Department of Health and Human Services (HHS) has proposed a new recommendation for fluoride content in drinking water of $0.7 \mathrm{mg} \mathrm{F} / \mathrm{L}$, replacing the current guideline that specifies a level between 0.7 and $1.2 \mathrm{mg} \mathrm{F} / \mathrm{L}^{9}$. In Brazil, legislation establishing the procedures and responsibilities relating to the control and surveillance of water quality for human consumption ${ }^{2}$ has recently undergone public review ${ }^{6}$.

This study classified the water samples in accordance with recommendations published by the Collaboration Center for Oral Health Surveillance of the Health Ministry (CECOL/USP, $2011)^{6}$, taking into consideration both the benefits of fluoride in preventing dental caries and the risk of dental fluorosis. The document suggests three classifications based on the average maximum annual temperature of the locality, since the optimal 
fluoride concentration in drinking water is dependent on the level of water consumption. Higher levels are preferred in lower-temperature regions where water consumption is lower, whereas in higher temperature regions, the recommended fluoride levels are lower ${ }^{10}$. According to this classification, $51.36 \%$ of the 19,533 samples had fluoride levels within the optimum risk-benefit range.

Fluoride levels outside of the recommended parameters were observed during a previous research in the same region ${ }^{20,21}$. During a sixmonth analysis in 2005, Saliba, et al. ${ }^{21}$ (2006) reported that approximately $62 \%$ of the water samples were outside of the recommended fluoride concentration range. Another 36-month study found that approximately $43 \%$ of the samples from cities with only a single source of water were outside of the recommended parameters ${ }^{24}$. Deficiencies in fluoridation were also described in studies performed in other regions ${ }^{3,15}$.

Some cities undertaking water fluoridation had a majority of water samples outside the optimum range of fluoride levels. Most of these cities employed more than one water supply, promoting interconnection and mixing of water from different sources in the distribution system and making it difficult to maintain fluoride levels within the recommended range ${ }^{12}$. However, none of the deviations persisted for extended periods at any sampling site during the 7-year study, minimizing undesirable effects ${ }^{4}$.

Among the three cities that did not add fluoride, only one had a majority of samples within the recommended range. In that city, the source of supply already contained the recommended level of fluoride. In one of the remaining cities, $53.78 \%$ of the water samples contained less than $0.55 \mathrm{mg}$ $\mathrm{F} / \mathrm{L}$, while in the third city approximately $75 \%$ of the samples contained fluoride levels above 0.84 $\mathrm{mg} F / \mathrm{L}$, increasing the risk of dental fluorosis.

Only $8 \%$ of the water samples from cities adding fluoride exhibited fluoride levels above $0.84 \mathrm{mg} \mathrm{F} / \mathrm{L}$, and fluoride levels were above $1.44 \mathrm{mg} \mathrm{F} / \mathrm{L}$ in only $1.46 \%$ of the samples.

In two of the three cities performing water fluoridation in which most of the samples contained elevated fluoride levels, the water sources were deep wells that are known to naturally contain higher fluoride levels. This highlights the need to examine water distribution networks and to develop dilution and mixing procedures to optimize the use of the natural fluoride present in deep-water wells and achieve the desired fluoride concentrations ${ }^{7}$.

There was some variability among the samples from different sites in the same city, demonstrating the importance of selecting collection sites according to the number and location of the water supply. In addition to sample collection bottles, a document was sent each month to the cities requesting notification of any changes to the water distribution network caused by the opening or closing of any water supply. In order to assist the cities in achieving optimum fluoride levels, the results of the analyses were sent monthly to the secretaries of health, oral health coordinators, and those responsible for the water supply in each municipality.

The effect of fluctuations in fluoride concentration on the risk/benefit analysis is dependent on the duration of the fluctuations. It is essential that the addition of fluoride be maintained without large fluctuations, since reduced levels provide minimal health benefits while wasting public resources and excessive levels promote undesirable effects ${ }^{4}$.

The findings of this study demonstrate the importance of longitudinal studies to assist in maintaining optimum fluoride levels in public water supplies.

\section{CONCLUSION}

Most samples from cities providing fluoridated water were within the concentration range providing the best combination of risks and benefits, reaffirming the safety of the method. High fluoride levels were observed in samples from deep wells. We suggest further studies to optimize the use of natural fluoride to reduce fluoridation costs and the risk of dental fluorosis.

\section{ACKNOWLEDGEMENT}

The authors would like to thank the Coordination of the Improvement of Higher Education Personnel (CAPES) and the National Council for Scientific and Technological Development (CNPq) for providing financial support for this research.

\section{REFERENCES}

1- Brasil. Ministério da Saúde. Lei no 6.050, de 24 de maio de 1974: dispõe sobre a obrigatoriedade da fluoretação das águas em sistemas de abastecimento. Diário Oficial da República Federativa do Brasil, Brasília; 1974.

2- Brasil. Ministério da Saúde. Secretaria de Vigilânica em Saúde. Coordenação-Geral de Vigilância em Saúde Ambiental. Portaria MS n. 518/2004. Brasília: Ministério da Saúde; 2005.

3- Catani DB, Hugo FN, Cypriano S, Sousa ML, Cury JA. Relationship between fluoride levels in the public water supply and dental fluorosis. Rev Saude Publica. 2007;41(5);732-9.

4- Catani DB, Tenuta LMA, Andaló FA, Cury JA. Fluorosis in rats exposed to oscillating chronic fluoride doses. Braz Dent J. $2010 ; 21(1): 32-7$.

5- Centers for Disease Control and Prevention. Ten great public health achievements: United States, 1900-1999. MMWR Morb Mortal Wkly Rep. 1999;48(12):241-3. 
6- Centro Colaborador do Ministério da Saúde em Vigilância da Saúde Bucal. Consenso técnico sobre classificação de águas de abastecimento público segundo o teor de flúor. São Paulo: Faculdade de Saúde Pública da Universidade de São Paulo; 2011. 7- Chae GT, Yun ST, Mayer B, Kim KH, Kim SY, Kwon JS. Fluorine geochemistry in bedrock groundwater of South Korea. Sci Total Environ. 2007;385(1-3):272-83.

8- Cury JA, Tenuta LM, Ribeiro CC, Paes Leme AF. The importance of fluoride dentifrices to the current dental caries prevalence in Brazil. Braz Dent. J. 2004;15(3):167-74.

9- Department of Health and Human Services. Proposed HHS recommendation for fluoride concentration in drinking water for prevention of dental caries. Federal Register. 2011;76(9):2383-8. 10- Galagan DJ, Vermillion JR. Determining optimum fluoride concentrations. Public Health Rep. 1957;72(6):491-3.

11- Instituto Brasileiro de Geografia e Estatística. Censo Demográfico: Características da população e dos domicílios: resultados do universo [online]. [cited 2011 Nov 20]. Available from: http://www.ibge.gov.br/home/presidencia/noticias/noticia_ visualiza.php?id_noticia $=2017 \&$ id_pagina $=1$.

12- Lodi CS, Ramires I, Buzalaf MA, Bastos JR. Fluoride concentration in water at the area supplied by the Water Treatment Station of Bauru, SP. J Appl Oral Sci. 2006;14(5):365-70.

13- McDonagh M, Whiting P, Wilson PM, Sutton AJ, Chestnutt I, Cooper J, et al. Systematic review of public water fluoridation. BMJ. 2000;321:855-9.

14- McKay FS. Relation of mottled enamel to caries. J Am Dent Assoc. 1928;15:1429-37.

15- Moimaz SA, Saliba O, Chiba FY, Saliba NA. External control of the public water supply in 29 Brazilian cities. Braz Oral Res. $2012 ; 26(1): 12-8$.
16- Olivati FN, Souza ML, Tenuta LM, Cury JA. Quality of drinking water fluoridation of Capão Bonito, SP, Brazil, evaluated by operational and external controls. Rev. odonto ciênc. 2011;26(4):285-90.

17- Peres MA, Antunes JL, Peres KG. Is water fluoridation effective in reducing inequalities in dental caries distribution in developing countries? Recent findings from Brazil. Soz Praventivmed. 2006;51(5):302-10.

18- Ramires I, Olympio KP, Maria AG, Pessan JP, Cardoso VE, Lodi $\mathrm{CS}$, et al. Fluoridation of the public water supply and prevalence of dental fluorosis in a peripheral district of the municipality of Bauru, SP. J Appl Oral Sci. 2006;14(2):136-41.

19- Saliba NA, Moimaz SA, Casotti CA, Pagliari AV. Dental caries of lifetime residents in Baixo Guandu, Brazil, fluoridated since 1953: a brief communication. J Public Health Dent. 2008;68(2):119-21. 20- Saliba NA, Moimaz SA, Saliba O, Barbosa TF. Fluoride content monitoring of the public water supply of the Northwest area of the state of São Paulo, Brazil: 36-month analysis. Rev Odonto Ciênc. 2009;24(4):372-6.

21- Saliba NA, Moimaz SA, Tiano AV. Fluoride level in the public water supply of cities from the northwest region of São Paulo State, Brazil. J Appl Oral Sci. 2006;14(5):346-50.

22- Tenuta LM, Cury JA. Fluoride: its role in dentistry. Braz Oral Res. 2010;24(Suppl 1):9-17.

23- United Nations. The Universal Declaration of Human Rights [online]. [cited 2012 Feb 9]. Available from: http://www.un.org/ en/documents/udhr/

24- United Nations. Universal Declaration of Water Rights. In: Ifrah G. Histoire de I'eau. Paris; 1992. 